\title{
Rural Road Infrastructural Challenges: An Impediment to Agricultural Development in Idanre Local Government Area of Ondo State, Nigeria
}

\author{
Samuel Oluwaseyi Olorunfemi
}

\begin{abstract}
Accessibility to the rural area by road is a key factor in achieving Sustainable Development Goals in pursuance of optimal survival these areas. Various rural development policies instituted in Nigeria to alleviate the condition of rural dwellers and to sustain agricultural development, yet the smooth accessibility desires of several rural areas impaired by poor rural road infrastructure. The resultant effect of this is low agricultural productivity in rural areas and food insecurity. Rural communities in developing countries are mostly disconnected from the major roads and public transport services that should provide them access to the economic and social opportunities in cities. To this end, the research examined how road infrastructural challenges have impeded the development of agriculture in Idanre Local Government Council Areas, Ondo State, Nigeria. A structured questionnaire was purposively and randomly administered to collect data from a total of 200 farmers across 20 villages in the study area. Analysis of data for the information retrieved from the respondents were carried out with aid of descriptive statistics while stepwise regression examination was done to test the hypothesis. Findings revealed a high cost of transportation and irregular transport services as a result of the poor state of the roads in the study area have hindered effective agricultural development. Results also indicated that motorcycles were the dominant means of transportation in the LGA. This among others resulted in an increasing rate of post-harvest loss because of the restrictive capacity of motorcycle and high cost of transportation. The study recommended the construction and rehabilitation of dilapidated roads infrastructure to enhance agricultural development in the study area.
\end{abstract}

Keywords: Agricultural productivity; Idanre; road infrastructure; rural area

Ghana Journal of Geography Vol. 12 (2), 2020 pages 108- 124

https://dx.doi.org/10.4314/gjg.v12i2.5 


\section{Introduction}

Rural areas in Africa are made up of people who are poor and characterized by a low educational standard. These Africa rural areas are capable of offering the highest opportunity capable of transforming the continent through adequate agricultural production reinforced by reliable and adequate transportation (Olorunfemi \& Adenigbo, 2017). Angmor (2012) opined that adequate road transportation is essential to agricultural development, as it will allow farmers to get inputs and data within a reasonable time and sell their harvest at realistic prices to cover their total cost with profits.

Rural Nigeria is yet to witness any rapid development despite her major role in the process of economic liberation before the beginning of oil production (Gbadamosi \& Olorunfemi, 2016). Various postulations have been made to be the reasons for the neglect of rural areas in Nigeria most especially in the provision of road infrastructures. Okakunori (2006); Ugwuanyi \& Chukwuemeka (2013); Olorunfemi \& Basorun (2013) revealed that lack of infrastructural facilities particularly the abandonment of road transport infrastructure has resulted in the pitiable quality of life with its consequential implication on the rural dwellers. Similarly, it has also limited the level of agricultural activities as most farmers find it difficult to transport their agricultural products to the urban centres where it will be needed (Olorunfemi and Adenigbo, 2017). This leads to a high rate of poverty among rural dwellers not because they are lazy but because their output does not commensurate to the economic value received. In a related view, Ajiboye (1995) noted that inadequate road infrastructure in most of the rural areas in Nigeria is responsible for the high cost of food majorly experienced in the urban centres of the country.

Olamigoke \& Emmanuel, (2013) noted that the development of a country and the local economy is hinged on the adequate, reliable and efficient transportation system. Road transportation has long been recognized as a major factor for accelerating rural development (World Bank 2008; Chakwizira \& Mashiri, 2009). Chakwizira, Whemachena \& Mashiri, (2010). More importantly, access to the low cost of road transportation makes it possible for farmers to bring raw materials from farms, mines fields and forests to factories and industries where it is being transformed into desire product (Chakwizira, Whemachena \& Mashiri, 2010). The authors further noted that to reduce the price of agricultural inputs, improve market access for agricultural products, facilitate access to agricultural extension services, enhancements of rural roads infrastructure and suitable transport services will be required. 
The significance of increasing rural infrastructure, most especially rural roads infrastructure, is not new (Marie-Agnès, 2013). This matter has long been recognized as the hub of development policies, sustained by the common postulation of development theorists that remote areas disadvantageous position vis-à-vis the economic prospect and social well-being could be improved with road construction (Bryceson et al., 2008, Marie-Agnès, 2013). It has also been noted that the development of rural road infrastructure will have positive effects on agriculture. Governments and private organisations must invest in the advancement of rural roads infrastructure because that will facilitate agricultural development and improve the living standards of the rural dwellers (Marie-Agnès, 2013).

Olorunfemi \& Adenigbo (2017) claimed that agricultural development is an indispensable factor for sustainable development in Nigeria, most especially in the area of food security. This implies that all harvests from agricultural activities will be demanded and consumed at a price which will be transformed into prosperity for farmers. To achieve this, the authors pointed out that transportation services have to be provided with adequate road infrastructure to move to produce to the market. But in a situation where this is not provided, produce are bound to perish, and this will translate into poverty for the farmers. In as much as this persists in Nigeria, sustainable development in food security will be difficult to achieve.

This paper, therefore, seeks to examine how rural road infrastructural impedes agricultural development in Idanre Local Government Council Area, Ondo State, Nigeria. This LGA represents the food hub of Ondo State where a lot of agricultural produce are sourced. The objectives of the study are as follows to: identify the social-economic characteristic of the people in the study area; assess their means of transportation available in the area; examine the major challenges facing farmers in moving agricultural products; and investigate the strategy used for the provision and maintenance of road infrastructure in the study area.

\section{Literature Review}

As briefly pointed out already, road infrastructure plays a significant role in the development and sustainability of rural environments, knowing fully that the rural areas are the hub for food production and centre for the production of raw material needed in the industries (Olorunfemi, 2018). Several authors have deliberated on numerous problems encountered by people living in rural areas, particularly in the area of mobility, which is very germane to the social and economic survival of any society. Gbadamosi \& Olorunfemi (2016) stressed that road transport infrastructure appears to be an important concern for rural dwellers. Fatoke (2013) also observed that the provision of basic 
infrastructure in developing countries is more available in urban centres compared to what is available in rural areas. The inequality in the distribution of basic infrastructure (road inclusive) in the rural is, perhaps responsible for the shortage of food which is prevalent today.

Donnges, Edmonds \& Johannessen,(2007) opined that roads are a crucial component of physical access, without which rural communities face much greater obstacles in obtaining necessary social services such as market, education, health, and other social services. With the above, the capability of taken advantage of surplus crop production and employment opportunities is strictly constrained. They further argued that physical access to the social amenities is not a Millennium Development Goal in itself. However, it plays a vibrant role in influencing the feasibility for attaining a number of the MDGs. Corroborating the above, Nathan Associates Inc (2013) pointed out that road infrastructure will ease transport costs and make isolated areas more accessible and facilitate economic activities. Nathan Associates Inc (2013) clarified that if rural roads are accompanied by other infrastructure, this can boost agricultural productivity, employment and as well increase rural income. Contrary to the above, lack of suitable access to transport infrastructure leads to high transport costs, lower market access for agricultural products, and damages due to spoilage and consequently reduced farmers' incomes. Inadequate road networks and communication services lead to poor agricultural services extension and truncate awareness of contemporary cropping systems and technology, which invariably reduced agricultural productivity.

Girvan (2007) posited that transport is very crucial to the increase in agricultural commodities. To advance the agricultural sector, investments in both hard and soft infrastructure are required. Yeboah (2015) listed roads and bridges as essential components of hard infrastructure and argued that they offers the structure within which soft infrastructure can be provided. Soft infrastructure according to Yeboah (2015) comprises of rural services such as transport, credit, banking, communications, extension, seed provision and marketing of rural produce among others. According to the World Bank (2007), the road is the greatest factor for market growth in terms of supply of inputs and output to and from farms; the most severe infrastructural blockage facing agricultural expansion particularly in the developing nations. In Nigeria and other developing countries, inadequate provision of rural roads infrastructure has led to high transport costs of moving agricultural outputs to the market as well as farm tools, which invariably contributes to food insecurity. For example, Yeboah (2015) noted that in sub-Saharan Africa, regular post-harvest damages are estimated to be over 40 per cent, comprising of about 70 per cent fruits and vegetables. 
Various researchers have worked on road infrastructure and its influence on agricultural development. For instance, Yaboah (2015) studied the influence of condition of Road transport Infrastructure on rural Agricultural Development in the Jaman South District, Ghana. He used questionnaires and structured interview schedule to collect data from 387 farmer households and 84 drivers employing simple probability sampling technique in the study area. Descriptive statistics were used in the analysis. The study found out that less than $45 \%$ of the road network in the district was properly engineered and classified to be good. It was found out that, the average farm distance from the community to the main road or nearest market was approximately $2500 \mathrm{~m}$ out of which approximately $1,375 \mathrm{~m}$ was in bad shape. The study recommended the development and expansion of road infrastructure in Jaman South District to boost agricultural development. Meanwhile, the researcher did not provide information on the state of road infrastructure available in the study area.

Chakwizira et al. (2010) established the connection within transport, agriculture and rural development as contained in the skills from Mhlontlo Local Municipality South Africa, integrated infrastructure Atlas. He used the bicameral method to provide a source for protrusive the transport and agriculture infrastructure in the study area. The study recommended that spatial mapping of infrastructure (road transport inclusive) should be provided to support integrated rural development plan, reinforce agricultural transformation and land use. However, the researchers also failed to highlight the state of the infrastructure investigated.

Orakwue, Umeghalu, \& Ngini, (2015) studied the effects of road transport on agricultural productivity in Ayamelum Local Government Area of Anambra State, Nigeria. They identified road transport as one of the most significant factors that affect the development of agriculture and the socio-economic status of people. Survey method was adopted for the study and structured questionnaire were directed to 20 farmers who were randomly nominated in each of the seven (7) communities in the study area. The authors relied on descriptive, graphical and analytical statistical approach for their data analysis. They find out that road transport possessed both negative and positive consequences on agricultural development and the general socio-economic status of the communities in the study area. The study recommended that adequate road infrastructure should be put in place to further facilitate agricultural production in the area.

Bonsu (2014) showed that adequate road transport infrastructure will provide suitable ways of transportation and distribution of agricultural products. He concluded that adequate road accessibility will in turn increase agricultural production although, the author did not provide information on the road transportation challenges encountered by farmers in the study area. In connection with the above, 
Adewole (2015) noted that roads remain one of the topmost facility of rural dwellers and must be at the centre of agricultural development policy. Gbadamosi \& Olorunfemi (2016) are of the view that Nigeria is mainly a rural community bearing in mind that greater part of her population exists in the rural areas and deeply reliant on agriculture as the main source of occupation but are unfortunately faced with transportation challenges ranging from poor transport services, bad road condition, to poor road infrastructure among others. They affirmed that transport challenges encountered in the rural areas of Nigeria have been recognised as a key limitation to the actualisation of active food production, child and maternal healthcare delivery that are paramount to the sustenance of rural areas.

Iyagba \& Anyanwu, (2012); Ajadi, (2010); Ugwuanyi \& Chukwuemeka, (2013) noted that different development-oriented programmes have been implemented in Nigeria, with a particular focus on regional development and food security. Some of the programmes according to them include: River Basin Development Authorities (RBDAs), National Directorate of Employment (NDE), National Directorate for Social Mobilization, Directorate for Food, Road and Rural Infrastructure (DFRRI), National accelerated Food Production (NAFPP), Better Life Programme, Agricultural Development Programmes (ADP), Millennium Development Project focused on Rural Infrastructure, Rural Banking Programme, and establishment of Microcredit Finance to offer financial support for rural economy and render financial services to the rural poor. Unfortunately, none of these policy programmes was able to fulfil its mandate because of poor coordination and implementation (Adewole, 2015). However, the majority of the issue accessed in the literature seems to focus on the role of transportation in enhancing agricultural productivity and marketing, the importance of road infrastructure etc. It is, therefore, obvious that a study that will provide the intricate of rural road infrastructural challenges as it affects agricultural development be carried out in Nigeria. This represents the research gap in knowledge which this study plans to fill.

\section{The study site}

Idanre Local Government Area of Ondo State has a population of 129,795 (National Population Census, 2006). The Local Government has two major towns Alade and Odode with several villages and is noted as one of the major foods hubs in Ondo State (Agunbiade, 2015). The study area shares common boundaries with Ondo East and Ile-Oluji-Oke-Igbo Local Government on the West, Akure South Local Government and Ifedore Local Government in the North, Owo Local Government to the East, Odigbo Local Government and Edo state on the South. Figure 1 shows the location of Idanre Local government in Nigeria and the selected rural areas for the study. 


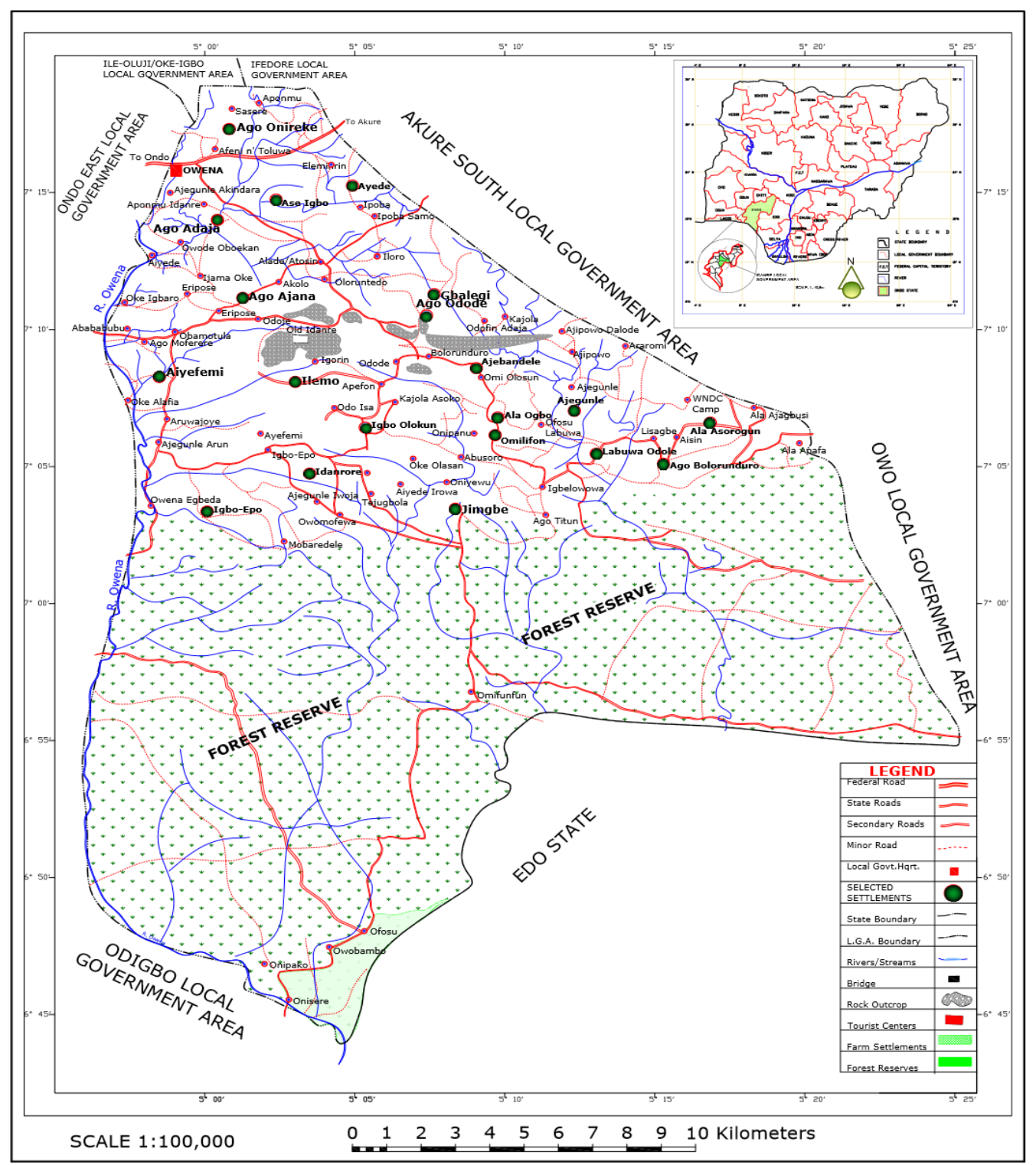

Figure 1: Map of Idanre Local Government showing the selected Villages for the study.

Source: Works Department, Idanre Local Government, 2018.

\section{Research Methodology}

The study relied on both Primary and secondary data sources to collect the required information for the study. Primary methods of data collection involved personal surveillance and questionnaire administration while secondary data were sourced from the books, a journal that is relevant to the study. In the course of this research, twenty farmers were randomly selected from 10 major villages across the study area. The relative population and size of these villages as hinted by the Head of 
Agricultural Department of the Local Government favoured their selection. These villages are Ago Onireke, Aso-Igbo, Ayede, Ago-Adajo, Ago-Ajana, Gbelegi, Aiyefemi, Ilemo, Ajebandele, Ajegunle, Igbo-Olokun, Ala-Ogbo, Omilifon, Labuwa, Ago Bolorunduro, Ala Asorogbon, Jimgbe, Igbo-Epe, Idanrore and Ago Odode. This implies that two hundred (200) copies of questionnaires were purposively administered to the farmers in the selected villages in Idanre Local Government Area of Ondo State, Nigeria. The purposive sampling is to ensure that only the farmers who were members of each of the selected villages were sampled. The random technique is to certify that individual farmers have an equal opportunity to be sampled. The data retrieved for the study were analysed using simple descriptive statistics in form of frequency counts and percentages while stepwise regression examination was adopted to test the hypothesis.

\section{Findings and Discussion}

\section{Socio-Economic Characteristics}

The variables examined for socio-economic characteristics of household (farmers) in the study include gender, marital status, age, educational status, income and household size. The variables examined included gender, marital status, age, educational status, income and household size. The gender of the household farmers in the study revealed that $72.5 \%$ were male and $27.5 \%$ were female. This shows that males were more engaged in farming activities in the study area than their female counterpart. This may be because the males are more active and can withstand the rigour of farming than females. In addition, the males being head of the family, have to provide for the family while females support in their little ways. To corroborate this, Asogwa (2012) asserted that men mostly engaged in farming activities for income generation and the up-keep of their families. The investigation into their marital status shows that $20.5 \%$ were single, $60.5 \%$ were married, $14.0 \%$ widowed and 5.0\% were divorced. This implies that married people were actively engaged in farming activities than other segments of marital status.

The educational status of the respondents shows that $27.0 \%$ are without formal education, $45.0 \%$ had primary school education, $17.0 \%$ got secondary education and $11.0 \%$ attained tertiary education. This indicates that the bulk of respondents are primary school certificate holders. This may affect the capacity of the farmers to grapple modern agricultural production techniques. The high rate of poverty is also responsible for the low standard of education acquired by the farmers since the pursuit of 
higher education is capital intensive. Consequently, many respondent's recourse to farming was because of their inability to afford the cost of pursuing secondary/tertiary education.

The age variable revealed that $10.0 \%$ of the farmers fall within the age bracket of $20-30$ years, $22.5 \%$ were within $31-40$ years, $27.5 \%$ fall within $40-50$ years, $35.0 \%$ were between $51-60$ years and $5.0 \%$ were 60 years and above. From the above, the active age group, precisely the youths were not adequately engaged in farming practices in the study area. This may be due to the absence of social amenities necessary for improved living in the study area. As such, the majority of them relocate to the urban centres where they can enjoy such amenities. These pose threat to agricultural productivity in the rural area and food insecurity in Nigeria. However, this situation calls for policy to encourage the youths to participate in farming by making rural areas conducive for living through the provision of infrastructures. This is required to reduce rural-urban migration in Nigeria (Olorunfemi and Adenigbo, 2017)

The household size of the farmers in the study area indicated that majority (55.0\%) of the farmers had 7-9 household size. In terms of income, majority of the sampled farmers earned between 300,001 (\$833.34)-\$400,000 (\$1111.1) (47.5\%) annually. Others earned between 100,001(\$277.78) - N200, 000 (\$555.56) (12.0\%), 200,001 (\$555.56)- \$300,000(\$833.33) (16.0\%), — $400,001(\$ 1111.11)$ - 500,000 (\$1388.89) (19.0\%) and only 5\% of the respondents earned $\$ 500,000$ (\$1388.89) and above.

\section{Means and Cost of Transportation of Agricultural Products}

Means and cost of transportation are significant factors to consider in the movement of passengers, goods and workers. Table 2 revealed the means of transporting agricultural products from the rural area of Idanre Local Government to the urban centres to include head-pan/wheel biro, bicycle, motorcycle, car/bus and truck. The analysis shows that $7.5 \%$ of the household farmers in the area relied on head-pan/wheel biro and car/bus to move their agricultural produce from farm to house and the market centres respectively, $17.5 \%$ of them used bicycle, $57.5 \%$ relied on the motorcycle and $10.0 \%$ on the truck. It is noted from the above that majority of household farmers surveyed in the study area used motorcycle to transport their farm produce from farm to house and the market centres. The adoption of the motorcycle as the major means of transportation of agricultural products in the area was as a result of the poor condition of roads in the area. Majority of the roads in the study area were untared and those that were tarred had dilapidated; characterised with deep potholes that can cause serious damage to the vehicle. However, the cost of transportation in the study area shown that 
majority of the farmers spent about $\$ 1,000(\$ 2.78)$ - $\$ 1,500(\$ 4.17)$ on transportation per trip from their respective villages to the market centre. This above scenario coupled with inadequate transport services led to the wastage of agricultural produce in the area which invariably results in food insecurity.

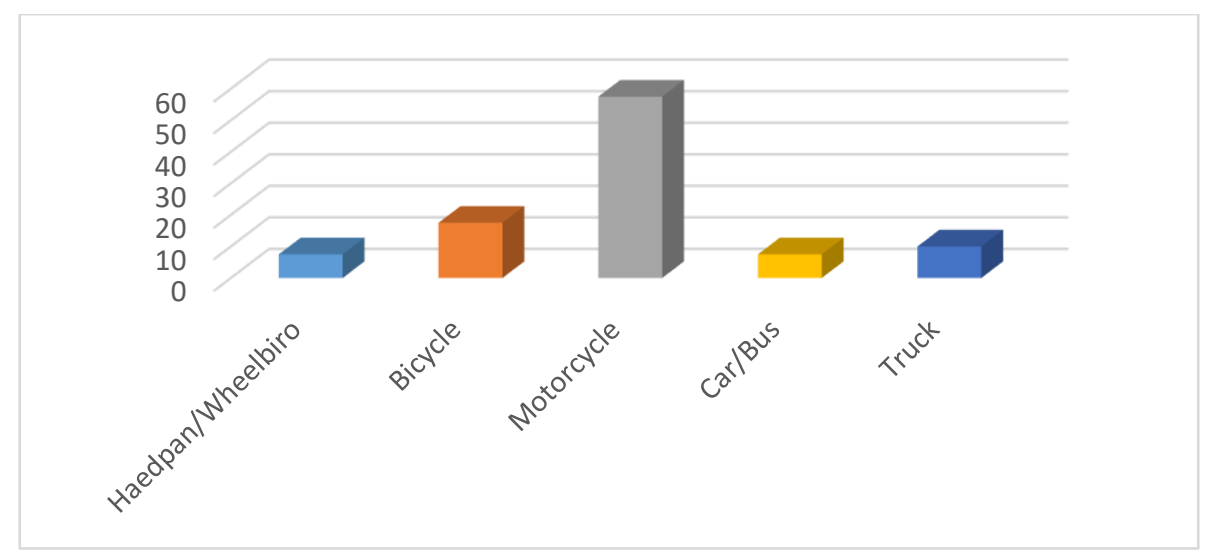

Figure 2a: Mean of Transportation of Agricultural Produce

Source: Author's Field Work, 2018

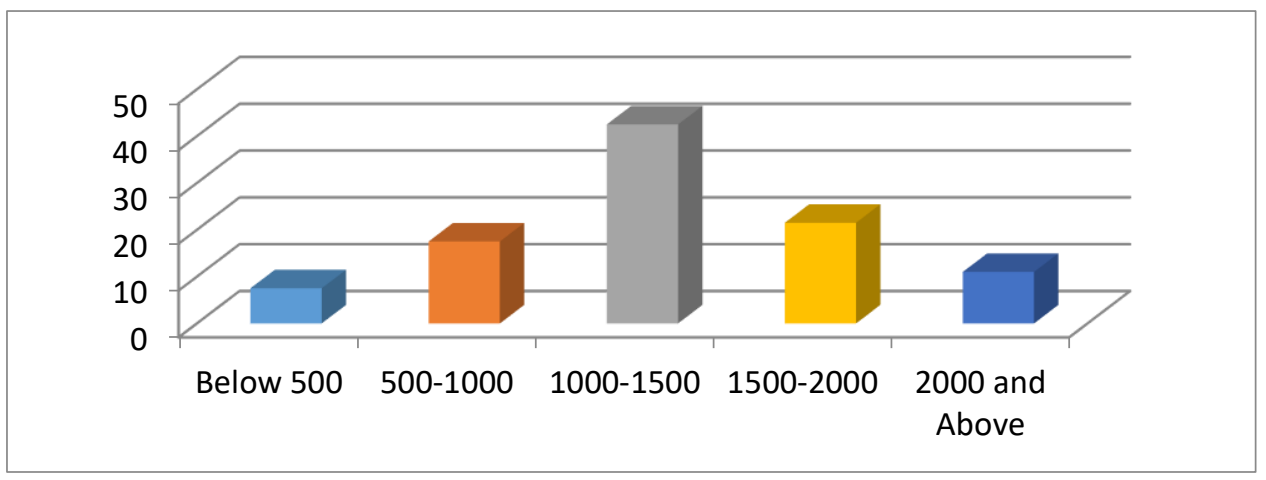

Figure 2b: Cost of Transportation.

Source: Author's Field Work, 2018

\section{Challenges encountered by Farmers in Moving Agricultural Produce to Urban Market}

The challenges militating against farmers in moving their agricultural produce to the urban market as identified in the study area include overloading, irregular transport services, vehicle damage, wastage of farm produce on transit and poor road condition. To determine the most significant challenges as stated above, stepwise regression analysis of the identified challenges was employed. The reason for the adoption of the stepwise regression is because it can remove variables that are not significant in a model.

Table 2 shows two models with multiple correlation coefficient $\mathrm{R}=0.696$ for model 1 which indicates a strong and positive correlation between challenges faced by farmers and high cost of transportation. 
Model 2 with $\mathrm{R}=0.725$ shows that a strong relationship exists between challenges faced by farmers and irregular transport services and the high cost of transportation. This indicates that the high cost of transport and irregular transport services are the major challenges facing the household farmers in moving their agricultural products in the study area. The $\mathrm{R}^{2}$ value showing 0.484 and 0.526 for model 1 and model 2 respectively show that the variable can explain $48.2 \%$ and $52.1 \%$ of the variance in the variables that influence the challenges facing household farmers in moving their farm produce to the urban centres.

Table 2: Model Summary

\begin{tabular}{lrrrr}
\hline Model & $\mathrm{R}$ & R Square & Adjusted R Square & Std. error of the Estimate \\
\hline 1 & $.696^{\mathrm{a}}$ & 0.484 & 0.482 & 0.225 \\
2 & $.725^{\mathrm{b}}$ & 0.526 & 0.521 & 0.217 \\
\hline
\end{tabular}
a. Predictors: (Constant), High cost of transportation
b. Predictors: (Constant), High cost of transportation, Irregular transport service
Source: Author Field Work, 2018.

The adjusted $\mathrm{R}^{2}$ is an attempt at improving the estimation of $\mathrm{R}^{2}$ in the population. The index is adjusted down to compensate for change increase in $\mathrm{R}^{2}$ with bigger adjustments for sets of explanatory variables. The value of this adjusted $\mathrm{R}$ square is a revised estimate for $69.6 \%$ and $72.5 \%$ of the variance of the challenges faced by farmers in moving agricultural products in the area, can be explained by the influence of the high cost of transportation and irregular transport services.

The ANOVA result for model 1 in Table 3 represents an F-Test equal to 186.043 when the explanatory variables are set at zero. The result shows $\mathrm{F}(1,198)=186$ significance at $\mathrm{p}=.0 .000$, leading to the conclusion that high cost of transportation significantly influences the challenges faced by farmers in moving their farm products to the market in the area. Model 2 shows $\mathrm{F}(2,197)=109$ that is significant at $\mathrm{p}=0.000$, which implies that irregular transport services significantly influence the challenges faced by the farmers in the study area.

\begin{tabular}{|c|c|c|c|c|c|c|c|}
\hline Model & & Sum of Squares & Df & & $\begin{array}{c}\text { Mean } \\
\text { Square }\end{array}$ & $\mathrm{F}$ & Sig. \\
\hline 1 & Regression & 9.446 & & 1 & 9.446 & 186.043 & $.000^{\mathrm{b}}$ \\
\hline
\end{tabular}




\begin{tabular}{llrrrrr} 
& Residual & 10.054 & 198 & 0.051 & & \\
& Total & 19.5 & 199 & & & \\
\hline \multirow{2}{*}{2} & Regression & 10.258 & 2 & 5.129 & 109.32 & $.000^{c}$ \\
& Residual & 9.242 & 197 & 0.047 & & \\
\hline & Total & 19.5 & 199 & & & \\
\hline
\end{tabular}

Table 3: ANOVA Result model

a. Dependent Variable: Does road transport challenge affect your agricultural productivity
b. Predictors: (Constant), High cost of transportation
c. Predictors: (Constant), High cost of transportation, Irregular transport service
Source: Author's SPSS Computation, 2018 .

The coefficient of regression for challenges facing farmers in moving their farm products to the market is presented in Table 4. This provides the estimates of the regression coefficient, standard errors of the estimates, t-tests that a coefficient takes the value zero, and confidence intervals alongside the collinearity statistics.

For model 1 where the variables were regressed stepwise, only the high cost of transportation was significant as a major challenges facing farmers in the study area with a coefficient of 0.205 which is significant at $\mathrm{p}<0.05$. This implies that the challenges faced by farmers will increase by $20.5 \%$ for every additional score on the high cost of transportation in model 1 . In the case of model 2 , the stepwise regression accounted for two variables which are high cost of transportation and irregular transport services. The coefficient shows 0.314 for the high cost of transportation and 0.87 for irregular transport services. The result implies that the challenges faced by the farmer will increase by $31.4 \%$ for an additional score on the high cost of transportation and $87 \%$ for an additional score on irregular transport service. This shows that the variables regressed are major challenges faced by farmers in the study area to move their agricultural products to the urban markets. Corroborating the above, Abdulkadir (2014) noted that high transport charges constitute an important obstacle to adequate access to both social and marketing facilities. Consequently, the high expenditure incurred by the farmers/marketers especially due to poor roads, poor transport services, high or multiple taxes during transportation, increased the market cost, which negatively affects the marketing margin (Asogwa et al., 2013).

The collinearity statistics determines the level of multicollinearity in the analysis. The collinearity statistics for model 2, which has more than two variables, with Tolerance greater than 0.1 and VIF less than 10 indicated that the model, is free of collinearity which implies that no variables influence each other.

Table 4: Regression Coefficient 


\begin{tabular}{|c|c|c|c|c|c|c|c|c|}
\hline \multirow{2}{*}{ Model } & & \multicolumn{2}{|c|}{ Unstandardized Coefficients } & \multirow{2}{*}{$\begin{array}{c}\text { Standardized } \\
\text { Coefficients } \\
\text { Beta } \\
\end{array}$} & \multirow[t]{2}{*}{$\mathrm{t}$} & \multirow{2}{*}{ Sig. } & \multicolumn{2}{|c|}{$\begin{array}{l}\text { Collinearity } \\
\text { Statistics }\end{array}$} \\
\hline & & B & Std. Error & & & & Tolerance & VIF \\
\hline \multirow[b]{2}{*}{1} & (Constant) & 1.067 & 0.067 & & 16.003 & 0 & & \\
\hline & $\begin{array}{l}\text { The high cost of } \\
\text { transportation }\end{array}$ & 0.205 & 0.015 & 0.696 & 13.64 & 0 & 1 & 1 \\
\hline \multirow{3}{*}{2} & (Constant) & 0.931 & 0.072 & & 12.946 & 0 & & \\
\hline & $\begin{array}{l}\text { The high cost of } \\
\text { transportation }\end{array}$ & 0.314 & 0.03 & 1.064 & 10.51 & 0 & 0.235 & 4.263 \\
\hline & $\begin{array}{l}\text { Irregular transport } \\
\text { service }\end{array}$ & 0.087 & 0.021 & -0.421 & -4.158 & 0 & 0.235 & 4.263 \\
\hline
\end{tabular}

Dependent Variable: Does challenges faced by the farmer

Therefore, the model equation for the analysis will take:

Model 1: Challenges faced by farmers $=0.205$; High cost of transport+e

Model 2: Challenges faced by farmers $=0.314$; High cost of transport +0.871 Irregular transport service+e

Source: Author Field Work, 2018.

\section{Condition of Road Infrastructure}

Rural road Infrastructure according to Ali (2013) includes rural roads/tracks, and paths generally recognised as community roads with facilities such as road sign, footbridge, drainage system, bus stop shelter among others. The road infrastructures noticeable in the study area include the roads/farm track, bridges, road sign and drainage facility. The condition of the above road infrastructure was measured using 5 points Likert scale 'poor', 'fair', 'good', 'very good' and excellent. The analysis revealed that the available road and drainage system in the study area are poor. This is because the majority of roads/track available in the selected villages were untared and this impedes easy vehicular movement most especially during the raining season.

The poor condition of the roads in the study area is attributed to the poor drainage system. Most of the roads leading to the villages lack proper drainage facility that should prevent soil erosion, flooding and control flow of water along the road corridors. Where it is available, it is often blocked and filled up by sand and debris, thereby making the road unsafe for the users, particularly during the raining season. The above situation propelled the majority of farmers to rely on the use of motorcycle for the transportation of farm produce in the area. The aftermath of the above situation is the high cost of transporting both passenger and agricultural products from the area to the city centre.

The bridges and road signs in the area are fair in nature. This is because most of the bridges and road signs along the roads leading to the selected villages are still visible and functioning. Although, some of them need to be repaired to serve the desired purpose. 
Table 5: Condition of Road Infrastructure

\begin{tabular}{llllllll}
\hline $\begin{array}{l}\text { Road } \\
\text { Infrastructure }\end{array}$ & Poor & Fair & Good & Very Good & Excellent & $\begin{array}{l}\text { Weighted } \\
\text { Mean }\end{array}$ & Remark \\
\hline Road & $150(75.0 \%)$ & $37(18.5 \%)$ & $8(4.0 \%)$ & $5(2.5 \%)$ & 0 & 1.34 & Poor \\
\hline Bridge & $135(67.5 \%)$ & $41(20,5 \%)$ & $12(6.0 \%)$ & $5(2.5 \%)$ & $7(3.5 \%)$ & 1.54 & Fair \\
\hline Road Sign & $121(60.5 \%)$ & $49(24.5 \%)$ & $21(10.5 \%)$ & $5(2.5 \%)$ & $4(2.0 \%)$ & 1.61 & Fair \\
\hline $\begin{array}{l}\text { Drainage } \\
\begin{array}{l}\text { System } \\
\text { Facility) }\end{array}\end{array}$ & $161(80.5 \%)$ & $21(10.5 \%)$ & $10(5.0 \%)$ & $5(2.5 \%)$ & $3(1.5 \%)$ & 1.34 & Poor \\
\hline
\end{tabular}

Note $:<1.5=($ Poor $), 1.5-2.4=($ Fair $), 2.5-3.4=($ Good $), 3.5-4.4=($ Very Good $)$ and $4.5-5.0$ $=($ Excellent $)$

Source: Author's Field Work, 2018.

\section{Strategy for the Provision and Maintenance of Rural Road Infrastructure}

Table 6 indicated that the strategy for the provision and maintenance of road infrastructure in the study area. From the field survey, 5.0\% of the household farmers opined that road infrastructure is provided and maintained in the area through a private organization, $20 \%$ claimed community participation effort, $24.0 \%$ affirmed government effort and $51.0 \%$ of them attributed it to government and community efforts. From the above, it is shown that provision and maintenance of rural road infrastructure in Idanre Local Government are done majorly through government and community participation efforts. This is in agreement with the findings of Agunbiade (2015) that rural road infrastructure provision and maintenance is usually carried out in Idanre Local Government Area through the effort of government and community dwellers.

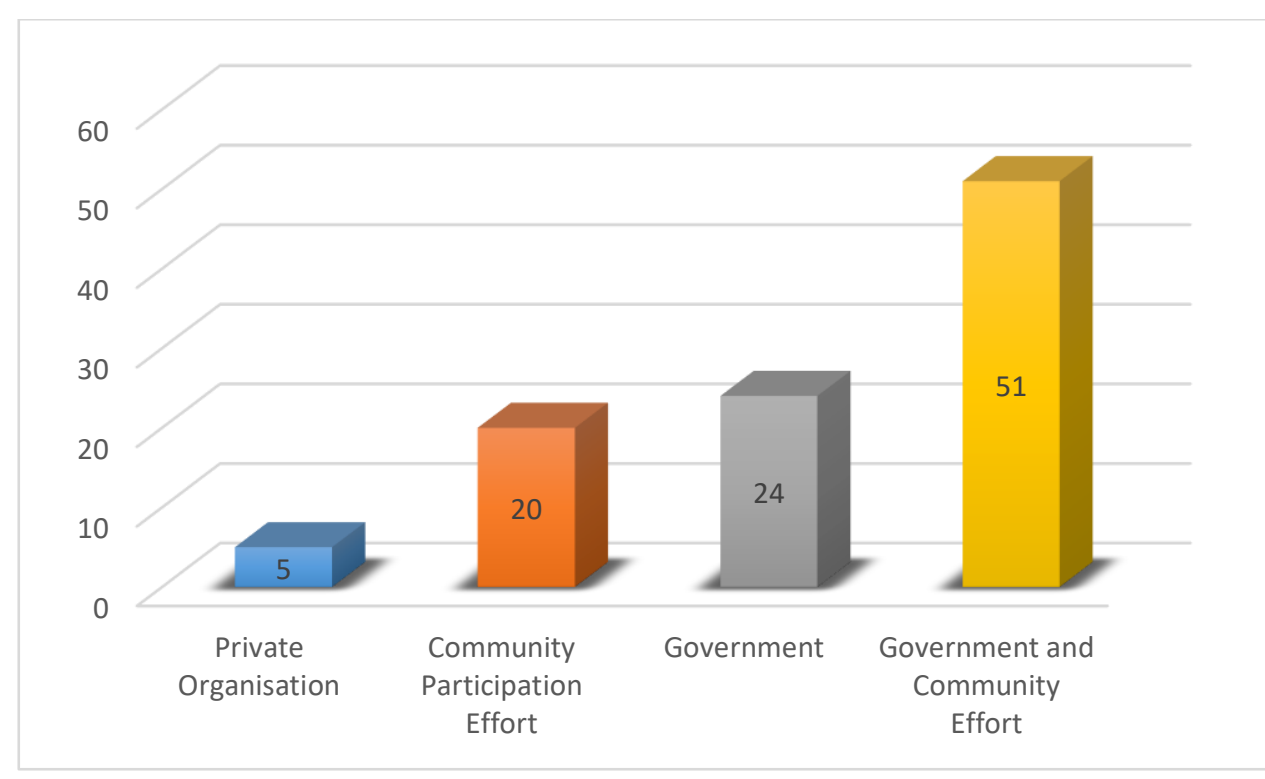

Figure 3: Strategy for the Provision and Maintenance of Rural Road Infrastructure Source: Author's Field Work, 2018 


\section{Conclusion and Recommendations}

The study examined how rural road transportation challenges have hindered agricultural development in Idanre Local Government Area of Ondo State, Nigeria. Findings have established that males dominated the household farmers surveyed in the study area, the majority were married and possessed primary school certificate and were between the ages of 51-60 years.

A considerable proportion of the rural dwellers conveyed themselves and their farm products to the city centres with the aid of motorcycle. Stepwise regression analysis showed that the high cost of transportation and irregular transport services are the major challenges confronting movement of agricultural products to the urban markets. Road and drainage facility in the area is poor while the bridges and road signs are fair.

To improve agricultural development in the area, social services such as market, hospital, good road, school, hospital, electricity, water, recreational facilities, and police post among others should be provided by the government in conjunction with a private organisation to better the life of dwellers in the villages across Idenre Local Government. In general, this will motivate farmers most especially the young ones to stay in the rural area and engage in farming activities to enhance food security and reduce rural-urban migration.

To reduce the high cost of transport and irregularly transport services in the area, there is a need for the provision of adequate road transportation facilities. This will involve the construction, expansion and maintenance of all rural roads in the study area. This can be achieved through the partnership of Ondo state Government with Idanre Local Government. This will not only create an access opportunity for the farmers to transport their farm products to the urban market, but it will also boost agricultural production which will, in turn, increase farmers' income and reduce poverty among rural farmers. 


\section{Reference}

Abdulkadir, B.U (2014). Analysis of Condition of Rural Road Transport in Kwara State, Nigeria. European Scientific Journal 10 (5):288-307.

Adewole, E.A (2015).The Regional Development Implications of Cassava Production in Ikere-Ekiti, Nigeria. Unpublished Master Thesis Submitted to Department of Urban and Regional Planning, Federal University of Technology, Akure.

Agunbiade, K.K (2015). An assessment of Provision of Transport Infrastructure on Rural SocioEconomic Development in Ondo State. Master Thesis Submitted to the Department of Transport Technology, Federal University of Technology Akure, Nigeria.

Ajadi, B. (2010) "Poverty Situation in Nigeria: An Overview of Rural Development Institutions" Pakistan Journal of Sciences 7 (5): 351 - 356.

Ajiboye A.O. (1995), Transportation and Distribution of Agricultural Products. A case study of Kolanut production in Remo land Ogun State. Unpublished M.Sc Transport Studies Thesis Ogun State University, Ago-Iwoye.

Ali, A.N (2013).Constraints to Sustainable Rural Transport Infrastructure Development in Enugu State, Nigeria. Journal of Sustainable Development in Africa 15 (2): 41-54.

Angmor, E.N (2012) The Role of Road Transportation Service in the Development of Traditional Market's: A Case of Asesewa and Agormanya Traditional Markets in the Eastern Region, Ghana. Master Thesis Submitted to the School Of Graduate Studies, Kwame Nkrumah University of Science And Technology, Ghana.

Asogwa, B.C, Ezihe, J.A, and Ater, P.I (2013).Socio-economic Analysis of Cassava Marketing in Benue State, Nigeria. International Journal of Innovation and Applied Studies 2 (4): 384-391.

Bonsu, D. (2014) Road Transport and Agriculture: A Comparative Study of the Implications of Road Access for Subsistence Agriculture in Northern Ghana. Master Thesis submitted to the Department of Geography, University of Bergen.

Bryceson, D., Bradbury, A. and Bradbury, T. (2008) 'Roads to poverty reduction? Exploring rural roads' impact on mobility in Africa and Asia', Development Policy Review 26(4): 459-482.

Chakwizira, J. \& Mashiri, M. (2009). The contribution of transport Governance to Social Economic Development in South Africa. SATC, 2009 Pretoria South Africa

Chakwizira, J., Whemachena, C., \& Mashiri, M. (2010). Connecting Transport, Agriculture and Rural Development: Experiences from Mhlontlo Local Municipality integrated infrastructure Atlas. Proceeding of the $29^{\text {th }}$ South African Transport Conference (SATC, 2010) Pretoria, South Africa

Department for International Development (2005). Agriculture Investment in Africa: Overview Study; submitted by Cambridge Economic Policy Associates, Overseas Development Institute and TechnoServe, London: Department for International Development.

Donnges, C.; Edmonds, G.; Johannessen, B. (2007). Rural Road Maintenance Sustaining the Benefits of Improved Access. Bangkok, International Labour Office retrieved from www.ilo.org/publns on 8th August 2018

Fatoke, O (2013). Assessment of Accessibility of Rural Women to Healthcare Facilities in Ola-Oluwa Local Government Area, Osun State, Nigeria. Unpublished Master Dissertation Seminal Proposal of Department of Urban and Regional Planning, Federal University of Technology Akure.

Gbadamosi, K.T and Olorunfemi, S.O (2016).Rural Road Infrastructural Challenges: An Impediment to Health Care Service Delivery in Kabba-Bunu Local Government Area of Kogi State, Nigeria. Academic Journal of Interdisciplinary Studies 5(2):34-43

Girvan, N. (2007). Towards a single development vision and the Role of the single economy. Working Paper prepared In Collaboration with the CARICOM Secretariat and the Special Task Force on the Single Economy 
Iyagba, A. G., and Anyanwu, S.O (2012).Problems and prospects of cassava production in Rivers State, Nigeria: A case study of Oyigbo local government area. Agriculture and Biology Journal of North America. 3(7): 296-301.

Marie-Agnès, J (2013). Targeting infrastructure development to foster agricultural trade and market integration in developing countries: an analytical review. London, Overseas Development Institute.

Nathan Associates Inc (2013) Infrastructure Regional Agricultural Trade Environment (RATE) Summary: USAID Maximizing Agricultural Revenue through Knowledge, Enterprise Development and Trade (MARKET) Project.

Okakunori, O.K. (2006). Transportation Management. Enugu, Grovani Publishers

Olamigoke, E.A and Emmanuel, A.A (2013).The Role of Road Transportation in Local Economic Development: A Focus on Nigeria Transportation System. Developing Country Studies 3(6,): 4653.

Olorunfemi S.O (2018). Factors Impeding Food Security in Akutupa-Kiri, Nigeria. Paper presented at the Feed the Future Second Conference organized by the International Food Policy Research Institute in conjunction with USAID and Michigan State University, USA. 14-16, August 2018.

Olorunfemi S.O and Basorun J.O.(2013). Appraisal of Regional Mobility in Lokoja, Nigeria. Journal of Society and Communication 2013: 420-446

Olorunfemi, S.O and Adenigbo, J.O (2017).Road Transportation Challenges to Food Security in Ikere Ekiti Local Government Area of Ekiti State, Nigeria. Paper presented at the Quantitative Methods for Integrated Food and Nutrition Security Measurements-Lessons to be learned Conference organized by European Commission and International Food Policy Research Institute held at Thon Hotel Brussels, $15^{\text {th }}-17^{\text {th }}$ November 2017.

Orakwue, C.O Umeghalu, I.C.E and Ngini, J.O (2015).Effects of Road Transport on Agricultural Productivity: A Case Study of Ayamelum Local Government Area of Anambra State, Nigeria. International Journal of Applied Science Engineering 3(1)

Orakwue, C.O Umeghalu, I.C.E and Ngini, J.O (2015).Effects of Road Transport on Agricultural Productivity: A Case Study of Ayamelum Local Government Area of Anambra State, Nigeria. International Journal of Applied Science Engineering 3(1):1-4

Ugwuanyi, B.I and Chukwuemeka, E.O (2013) Enhancing Rural Development in Nigeria: Periscoping the Impediments and Exploring Imperative Measures. Singaporean Journal of Business Economics, And Management Studies, 1(8)55-61

World Bank (2007). A Decade of Action in Transport- An Evaluation of World Bank Assistance to the Transport Sector, 1995-2005. World Bank, Washington, DC. Accessed on $8^{\text {th }}$ August 2018 from http://www.worldbank.ord/

World Bank (2008), Agriculture for Development. World Development Report, 2008. Accessed on $8^{\text {th }}$ August 2018 from http://www.worldbank.ord/

Yeboah, S. (2015). Influence of Condition of Road Transport Infrastructure on rural Agricultural Development in the Jaman South District. Published Master Thesis Submitted To The School of Graduate Studies, Kwame Nkrumah University of Science And Technology, Ghana. 